\title{
O livre-arbítrio na ética de Abelardo ${ }^{1}$
}

\author{
Edsel Pamplona Diebe ${ }^{2}$
}

\begin{abstract}
Resumo: A concepção sobre livre-arbítrio em Abelardo foi definida na obra Theologia scholarium como a própria deliberação do indivíduo em fazer ou renunciar a algo. $\mathrm{Na}$ Ethica, essa ideia foi desenvolvida a partir da noção de voluntário. Em se tratando de pecado, base das discussóes da Ethica, Abelardo desenvolveu o conceito que conhecemos hoje como "moral da intenção". Nessa perspectiva de moral, o pecado só se sustentaria a partir da intençẫo do indivíduo, fruto do seu consentimento, ação livre e voluntária. A proposta do artigo é analisar de forma introdutória como a ideia de livre-arbítrio foi compreendida por Abelardo em relaçáo ao pecado e em relaçáo à vontade de Deus, posicionamento que colaborou para sua condenação no Concílio de Sens, em 1140.
\end{abstract}

Palavras-Chaves: Pedro Abelardo (1079-1142). Ética. Livre-arbítrio. Voluntário. Consentimento.

A ética de Abelardo se forma basicamente a partir de três obras: Ethica seu scito te ipsum (Ethica), Collationes ou Dialogus inter philosophum, judaeum et christianum e Commentaria super sancti Pauli epistolam ad Romanos. Contudo, as obras de teologia também abordaram problemas éticos: Theologia summi boni, Theologia christiana e Theologia scholarium.

Em relação à Ethica, a primeira parte da obra foi dedicada ao estudo da moral, conhecida atualmente como "moral da intenção", que visou a estabelecer a relação do indivíduo diante do pecado. Abelardo discorreu sobre o desenvolvimento de uma moral que se relacionava diretamente com hábitos e costumes, vícios e virtudes do indivíduo, que poderia conduzi-lo tanto às boas quanto às más ações e poderiam ou não resultar em pecado.

${ }^{1}$ Conferência apresentada no I Colóquio de Filosofia Patrística e Medieval da PUC-SP, em 27/8/2019.

2 Doutora em Filosofia pela Universidade Federal de Santa Maria (UFSM), Santa Maria, RS - Brasil. (D) https://orcid.org/0000-0002-6888-0652 E-mail: edseldb@gmail.com

http://dx.doi.org/10.1590/0101-3173.2019.v42esp.13.p231 
O termo arbitrium aparece na Theologia scholarium com a seguinte definição: "O livre-arbítrio certamente é da alma a própria deliberação ou julgamento pelo qual uma pessoa qualquer se propóe ou a fazer algo ou a renunciar a algo." (ABELARDO, 1855, p. 1110). Já na Ethica, não aparece o termo arbitrium, mas houve o desenvolvimento da noção de indivíduo a partir do termo voluntas. King (1995) chamou atenção para a tradução de voluntas em Abelardo. Alguns comentadores traduziriam o termo por "vontade" e o próprio King por "desejo", pois concebeu o termo como próximo da noção moderna de desejo. Para King (1995, nota 6, p. 3),

\begin{abstract}
o argumento de Abelardo é um pouco obscurecido para o leitor moderno, já que ele usa o termo voluntas para desejo, muitas vezes enganosamente traduzido como "vontade" [...]. Abelardo claramente não pretende falar sobre uma faculdade da alma, ou acerca de voliçóes particulares, mas sobre desejos em algo igual ao sentido moderno. Em seu Comentário sobre "Romanos" (207-209), Abelardo distingue entre velle no sentido de voluptas, desiderium e delectatio, e no sentido de approbare. Os sentidos anteriores são relevantes para a Ética, e então eu devo traduzir em toda parte voluntas como "desejo".
\end{abstract}

Pensar o termo voluntas em relação ao indivíduo significa que o pecado, no interior dessa concepção moral, não será tratado como algo alheio ou mesmo inconsciente, mas como algo intencional, que parte da deliberação do indivíduo, da sua vontade, pois, segundo Abelardo (1971, p. 16), "todo pecado, diríamos, é voluntário”, logo, todo pecado é fruto do livre-arbítrio.

\title{
1. Conceito de PECAdo Na Ethica
}

O conceito de Abelardo sobre pecado contribuiu para sua condenação no Concílio de Sens, em 1140. Guilherme de Saint-Thierry, ao ler a Theologia de Abelardo, provavelmente a scholarium, listou 13 teses que considerou heréticas e as enviou a São Bernardo e ao bispo de Chartres, Godofredo de Lèves. Abelardo foi convocado informalmente à retrataçáo, mas não a fez prontamente e escreveu uma carta ao bispo de Sens pedindo um concílio para que pudesse se defender das acusaçôes. Nesse período, houve o concílio proposto e a redação de 18 cartas de São Bernardo contra o posicionamento de Abelardo, que denominou "erros de Abelardo" (Carta 190), sobre as interpretaçóes que fez de alguns preceitos cristáos, principalmente sobre o pecado, a fé e a Trindade. $\mathrm{O}$ concílio decidiu sentenciar 19 teses contra Abelardo. O Papa Inocêncio II encerrou as discussóes 
a respeito do concílio e deu seu veredito, mantendo a decisão de condenação do concílio. Escreveu uma carta ao bispo de Sens (Bula testante apostolo) confirmando a pena de Abelardo, a excomunhão. Após receber a sentença, Abelardo foi afastado da docência e passou o último ano de sua vida em Cluny, sob os cuidados do abade Pedro, o Venerável (ZERBI, 1972).

A proposta de moral abelardiana acerca do indivíduo e sua relação com pecado foi uma concepção divergente de sua época. $\mathrm{Na}$ carta 188 , por exemplo, São Bernardo de Clairvaux acusou Abelardo de ser disseminador de "novas ideias” em relação aos preceitos cristáos. Segundo Bernardo (1859, p. 353),

\begin{abstract}
lede, se agrada, o livro de Pedro Abelardo, que ele denomina de Teologia: efetivamente está à mão; visto que, assim como se vanglorie, seja lido muitas vezes por muitos na cúria; e ver quais coisas aí [na Teologia scholarium] se digam sobre a santa Trindade, sobre a geraçáo do Filho, e sobre a procissão do Espírito Santo e outras coisas inúmeras, em resumo, desacostumadas aos ouvidos e mentes católicas. Lede também outro [livro] dele, ao qual denominam [livro] das Sentenças; e ademais aquele [livro] que se intitula Conhece-te a ti mesmo [Ethica]; e observai em quanta terra semeada de sacrilégios e erros também eles próprios se tornem incultos: o que sinta sobre a alma de Cristo, sobre a pessoa de Cristo, sobre a descida de Cristo às regiōes infernais, sobre o sacramento do altar; sobre o poder de ligar e desligar [as chaves], sobre o pecado original, sobre a concupiscência, sobre o pecado do prazer, sobre o pecado da fraqueza, sobre o pecado da ignorância, sobre a obra do pecado, sobre a vontade de pecar.
\end{abstract}

Em relação à concepção de pecado apresentada na Ethica, Abelardo definiu algumas acepçóes, a saber: na primeira, o pecado foi apresentado como "desprezo de Deus" (contemptos creatoris) ${ }^{3}$ : "Assim, nosso pecado é o desprezo do criador, e pecar é desdenhá-lo, ou seja, não fazer, em absoluto, por ele, o que cremos que devemos fazer." (ABELARDO, 1971, p. 6).

Abelardo também compreendeu a ideia de pecado advindo da "ignorância" (ignorantia), um pecado cometido por infidelidade (infidelitas) a Deus, contudo, sem a devida consciência de ter sido infiel. Segundo Abelardo (1971, p. 56 e 58), “as obras também próprias do pecado, ou o que quer que corretamente não sabemos ou queremos, algumas vezes dizemos pecados". Nesse sentido, a infidelidade estaria na ação que gerou o pecado

\footnotetext{
${ }^{3}$ Concepção mencionada por Guilherme de Saint-Thierry na carta 326: "Que [para Abelardo] nada seria pecado, a não ser no consentimento do pecado e no desprezo de Deus.” (BERNARDO, 1859, p. 532). A versão desta carta de Guilherme de Saint-Thierry se encontra na Patrologia Latina n. 182, Opera omnia, de São Bernardo.
} 
e não no desprezo de Deus propriamente dito: "Ora, logo que dizemos que pecamos por ignorância, isto é, que fazemos o que náo convém, não tomamos 'pecar' enquanto desprezo, mas enquanto operação [ação de ter pecado]." (ABELARDO, 1971, p. 62).

Em relação às açôes do indivíduo, Rémusat (1855) analisou que para Abelardo o problema do pecado estaria na predisposição, na intencionalidade, sendo que para Abelardo "a moralidade está no agente, não está no ato; os atos não são nem bons, nem maus por si mesmos, pois é somente a vontade que é boa ou má [...]. O bem ou o mal está, portanto, em alguma coisa invisível, incorporal, interna." (RÉMUSAT, 1855, p. 481).

$\mathrm{Na}$ Confessio fidei universis ${ }^{4}$, escrita por Abelardo provavelmente após o Concílio de Sens, ele afirmou que são "culpáveis" (culpe) os atos cometidos por ignorância (ABELARDO, 1849, p. 721), contudo, o pecado por ignorância pode ser culpável, mas a intenção do indivíduo pode não ter sido má. Abelardo relembrou na Ethica o momento da crucificação, em que Cristo disse: "Pai, perdoa-lhes: não sabem o que fazem.” (Lc 23,20). Isso significa que, na visão de Abelardo, não se poderia tomar por pecado aquilo que o indivíduo desconhece ser um pecado. Como exemplo dos que pecam por ignorância, Abelardo citou na Ethica os homens que ignoram a Cristo e desconhecem a fé cristâ, as crianças pequenas (paruulus), que serão salvos pelos sacramentos (ABELARDO, 1971, p. 56). Conforme Chaves-Tannús (1996, p. 69), "para Abelardo, peca apenas aquele que sabe o que faz, que é capaz de discernir e, ainda assim, dá seu consentimento ao mal”.

Para tal concepçáo acerca do pecado por ignorância, Abelardo teve como fundamento a passagem da Carta aos Romanos 10,14: "Mas como poderiam invocar aquele em quem não creram? E como poderiam crer naquele que não ouviram? E como poderiam ouvir sem pregador?” Essa passagem tem fundamento também em Rm 2,14-15, em que São Paulo descreveu a situação dos pagãos que seguiam a lei da cidade e não a de Cristo, por não a conhecerem. Restou-lhes se apoiarem em suas consciências e nos pensamentos que defendiam:

Quando entáo os pagãos, não tendo lei, fazem naturalmente o que é prescrito pela lei; eles, não tendo lei, para si mesmos são a lei; eles mostram a obra da lei gravada em seus coraçôes, dando disso testemunho

${ }_{4}$ Tradução de Cléber Eduardo dos Santos Dias (2006), com a correspondência original no latim (Edição Victor Cousin, 1849). 
sua consciência e seus pensamentos que alternadamente se acusam ou defendem.

O pecado por ignorância se relacionou com o "pecado original" 5 (originale peccatum), ou seja, ao pecado de Adão, ao qual Jesus tomou para si em sacrifício: "Aquele que não conhecera o pecado, Deus o fez pecado por causa de nós, a fim de que, por ele nos tornemos justiça de Deus." (2 Cor 5,21).

Para Abelardo, muitas situaçóes levariam o indivíduo ao pecado, como os vícios do Espírito, que não são considerados pecado em si mesmos, mas uma inclinação às más açôes que geraria a oportunidade de pecar. Nesse sentido, Abelardo trouxe como exemplo a luxúria e a cólera e afirmou que esses vícios estão sempre presentes e podem ser tanto uma inclinação natural como um hábito 6 adquirido. De acordo com Abelardo (1971, p. 4), "ainda que os homens cessem de lutar, essas coisas [os vícios] não cessam, de modo que tanto mais perigosa lhes pareça ser a luta, quanto mais frequente, e tanto mais famosa a vitória, quanto mais difícil [os vícios de cessarem]".

$\mathrm{Na}$ Ethica, Abelardo relacionou pecado e livre-arbítrio com a intenção. Nesse sentido, o pecado só poderia acontecer necessariamente onde houvesse a intenção de pecar, portanto, seria voluntário. A intenção se relacionou também com a ideia de consentimento, que foi entendida por Abelardo como a "culpa da alma, o que merece danaçáo ou aquilo que nos coloca diante de Deus como réus" (ABELARDO, 1971, p. 4). Assim, para Abelardo, o pecado não estaria no vício em si, mas no consentimento do indivíduo, na consciência moral que o habilitaria a praticar o mal e, consequentemente, desprezar a Deus.

Para Abelardo, nem todas as açóes praticadas pelos indivíduos eram conscientes e, portanto, elas eximiriam, de certa forma, a responsabilidade (culpa) do indivíduo. Para Verbeke (1987, p. 92),

\footnotetext{
5 Carta 326: "Porque de Adão não contraímos a culpa, mas a pena do pecado original." (BERNARDO, 1859, p. 532). Também encontramos essa mesma ideia entre as teses condenadas pelo Concílio de Sens: "Que não contraímos a culpa a partir de Adáo, mas apenas a pena." (MEWS, 2001, p. 109).

${ }^{6}$ Provavelmente, Abelardo não teve acesso à ética aristotélica. Pertenceu à chamada lógica antiga (logica vetus). O que ele sabia sobre o tema "hábito" e "disposição" decorreu da leitura das Categoriae, de Aristóteles. A partir da segunda metade do século XII, temos o aparecimento das obras do novo Aristóteles (aristoteles novus) ou segundo Aristóteles com novas traduçóes feitas pelos árabes e pelas escolas de traduçáo, incluindo a mais famosa, de Toledo. Nesse período, todos os livros do Organon foram traduzidos. A conhecida lógica dos modernos (logica modernorum) são textos produzidos pelos próprios medievais a partir do século XII. (DE LIBERA, 1996, nota 34, p. 70).
} 
na ótica de Abelardo, o agir humano nem tanto surge das iniciativas conscientes e deliberadas cujo homem será completamente o autor. Ele se realiza por causa de certas aspiraçóes interiores, por exemplo, impulsos sensuais, dos quais o indivíduo não é verdadeiramente responsável; ele sofre o peso sem saber ainda de onde eles vêm [...] aos olhos de Abelardo todas as tendências são uma espécie de matéria bruta, um dado, de fato, que é mais importante para o comportamento.

Abelardo apontou a ideia de responsabilidade como um compromisso consciente que o indivíduo deveria assumir perante uma determinada situação, como no exemplo que citou como natural o desejo de se estar com uma mulher no sentido sexual7. Para Abelardo (1971, p. 12-13), "não é pecado desejar a mulher, mas sim consentir no desejo; e não é condenável a vontade do coito, mas sim o consenso da vontade". Nesse sentido, para Abelardo, o desejo por si só não seria pecado ${ }^{8}$.

Em relação à ideia de consentimento, se coloca necessário entender brevemente o uso do termo "assentir" (assentire) na Ethica de Abelardo. O termo remonta provavelmente à Predestinação dos santos, de Santo Agostinho, na concepção de crença em que "crer é pensar com assentimento". (AGOSTINHO, 1865, p. 963). Neste sentido, Chenu (2006) afirmou que para Abelardo a fé é um "assentimento voluntário", não passivo, livre (ad libitum) (CHENU, 2006, p. 963). Em Abelardo, o "assentir" agostiniano se colocou como sinônimo de "consentir", conceito que trabalhou na Ethica, na noção de pecado, que iria além de um simples "desvio" de conduta moral, mas se tornaria uma decisão interna, um consentimento ao mal, um desprezo de Deus. Assentir se desvencilha do campo puramente religioso e passa a ser "critério de moralidade" (CHENU, 2006, p. 20).

Abelardo utilizou o termo "assentimento" (assentire) na Ethica em duas passagens em que relacionou assentimento e desejo. Colocou que o desejo era "inevitável", "natural" e que poderia ocorrer sem que a consequência primordial fosse o pecado, pois faria parte da natureza humana o desejar. $\mathrm{O}$

\footnotetext{
7 Carta 326: "Porque ele [Abelardo] diz [que] nenhum pecado é cometido pela concupiscência, e pela delação e pela ignorância; e desse modo não é pecado, mas [faz parte da] natureza [humana]." (BERNARDO, 1859, p. 532).

8 Tese condenada no Concílio de Sens: "Que nem a obra nem a vontade nem a concupiscência nem o deleite que move a concupiscência seria pecado [para Abelardo], nem devemos querer que ela [a concupiscência] se extinga." (MEWS, 2001, p. 110).
} 
problema estaria, portanto, nas intençóes, posteriormente, no assentimento do mesmo (ABELARDO, 1971, p. 24 e 34).

Abelardo também relacionou o pecado com a tentação, que estaria ligada à vontade má e à própria fraqueza humana. Isso levaria os indivíduos a se entregarem facilmente ao pecado. Para Abelardo (1971, p. 34),

geralmente se diz [que a tentação] de qualquer inclinação da alma para fazer alguma coisa que náo convém, seja ela vinda da vontade seja vinda do consentimento. Humana, em verdade, se diz a tentação, sem a qual já a fraqueza humana dificilmente ou nunca pode resistir, como, por exemplo, a concupiscência carnal ou o desejo de um alimento agradável.

No que toca à vontade má, Abelardo a caracterizou em relação ao pecado e à virtude, "do mesmo modo, como a virtude [consistiria] na boa vontade, assim o pecado consistiria em uma má vontade" (ABELARDO, 1971, p. 6). Nesse sentido, Abelardo questionou a diferença entre pecado e vontade (como desejo): "Portanto dizes que essa vontade e o desejo vergonhoso é outra coisa que pecado?” (ABELARDO, 1971, p. 12). E respondeu afirmando novamente que o pecado não estaria, por exemplo, em desejar uma mulher, mas na intenção, no consentimento ao desejo e não propriamente na ação praticada de tentar possuir a mulher, que poderia ser boa ou má.

Analisamos até o momento as principais concepções de Abelardo sobre pecado e algumas condutas que levariam o indivíduo ao pecado, como vícios do espírito, vontade e tentação. Para Abelardo, o pecado só se consumaria na intenção, no consentimento do indivíduo. Mas como o indivíduo tomaria ciência do pecado? É o que vamos examinar a seguir.

\section{A Ética ou Conhece-te a tI MESMo A PARTIR do livRe-ARbítrio E DA VONTADE DE Deus}

A Ethica de Abelardo tem nome: seu scito te ipsum (conhece-te a ti mesmo - gnôti seautón), citação atribuída aos Sete Sábios (650-550 a.C.), inscrita no oráculo de Delfos, inspiração de Sócrates na busca da verdade. A escolha do título por Abelardo aponta sua busca em compreender os preceitos cristãos a partir da sua convergência com a filosofia. Isso significa que, se Abelardo escolheu discorrer sobre o pecado na Ethica, é porque o pecado não seria simplesmente transgressão a uma regra. O que está de fato em jogo em ter 
o pecado como alvo é a relação que pôde estabelecer com o próprio indivíduo, que sabe quando peca, salvo as vezes que desconheceu pecar, como o pecado atribuído à ignorância. Esse saber-se pecador remete o indivíduo à sua própria interioridade, à busca de conhecer a si mesmo. Nesse sentido, Estêvão (1992), sinalizou que a Ethica de Abelardo não é somente uma obra que visou discorrer sobre o pecado: "Toda a Scito te ipsum, ou o que conhecemos dela, está voltada para a questão do autoconhecimento.” (ESTÊVÃO, 1992, p. 51).

Todo indivíduo, para ser integralmente consciente de si mesmo (conhece-te a ti mesmo) deveria buscar a Deus. O fato de o pecado ser considerado voluntário, fruto do livre-arbítrio, não eximiria o indivíduo de pecar. Quando Abelardo apontou o pecado como desprezo de Deus, talvez quisesse dizer que seguir os preceitos de Deus era algo importante. Logo, se não se seguisse os preceitos de Deus, teria a possibilidade de pecar e é dessa forma que o indivíduo saberia que pecou, que iria além de transgredir uma regra, mas estaria desprezando a Deus. Logo, a vontade do indivíduo deveria se pautar nos desígnios de Deus. "Efetivamente, da mesma maneira que nos sentimos bem fazendo o que cremos agradar ao próprio Deus, assim náo nos sentimos bem fazendo o que cremos desagradar ao próprio Deus, e ao próprio [Deus] parecemos ofender ou desprezar." (ABELARDO, 1971, p. 6). Para esclarecer essa ideia, Abelardo se apoiou na passagem de João 6,38: "Pois desci do Céu não para fazer a minha vontade, mas a vontade daquele que me enviou." Verifica-se nessa busca interior do indivíduo um reconhecimento da vontade de Deus perante sua própria vontade.

Mas, se para Abelardo o indivíduo era dotado de livre-arbítrio, por que deveria preferir a vontade de Deus antes da dele mesmo? E se a vontade do indivíduo não coincidisse com a vontade de Deus? Na Ethica, Abelardo afirmou que o indivíduo deveria preferir a vontade de Deus à dele mesmo porque a natureza humana é cheia de vícios, de imperfeiçóes e de fraqueza. Vejamos um exemplo de como a vontade do homem nem sempre é boa: um homem que deseja comer frutas de um jardim particular e evita o pecado, não consentindo na sua vontade: “Onde, porém, está o desejo, ali sem dúvida [está] a vontade. [...] Aquele [que] reprime o desejo, não [o] extingue; mas porquanto não é arrastado até ao consentimento, não incorre em pecado." (ABELARDO, 1971, p. 14). Assim, para Abelardo, o pecado não estaria no desejo em si mesmo, mas na intenção de pecar. Rémusat (1855) apontou que para Abelardo o que valeria era sempre a 
intenção, ou seja, o que o homem pensava ou acreditava ser bom ou mal. Conforme Rémusat (1855, p. 482):

O que importa, é que ele [homem] pensa. Ora, o que ele pensa é determinado por sua educação, por suas opinióes, por sua vida, por sua natureza. Se ele crê ou acha boa uma ação, sua vontade não é má; e também o bem e o mal se tornam completamente subjetivos. A vontade se crê boa ou se crê má, é o que se chama frequentemente de intenção.

Isso significa que é a intenção ela mesma a égide da moral do indivíduo, a partir da qual Abelardo conceituou a sua ética. Mas como direcionar a intenção do indivíduo de modo que se prefira seguir a vontade de Deus sem ferir o livre-arbítrio? Estar em conformidade com Deus sem ferir o livre-arbítrio seria reconhecer a própria fraqueza, a própria dificuldade em resistir ao pecado. Seguir os mandamentos também seria um caminho, como, por exemplo, não desejar nada alheio. Abelardo (1971, p. 24) se referiu ao Deuteronômio 5,21: "Não cobiçarás a mulher do teu próximo; nem desejarás para ti a casa do teu próximo, nem o seu campo, nem o seu escravo, nem a sua escrava, nem o seu boi, nem o seu jumento, nem coisa alguma que pertença a teu próximo.”

Ainda se poderia tentar estar em conformidade com a vontade de Deus ao buscar modificar o desejo egoísta pelo desejo altruísta, ou seja, tentar ajudar o próximo pela caridade. Nesse sentido, todas as açóes do indivíduo deveriam se voltar para a "Nova Lei" (Nova Aliança). "A tese abelardiana da intençáo, enunciada no primado do amor para decidir a qualidade de nossos atos [...] reencontra a dialética paulina da 'nova lei', inscrita no coração e não mais em tábuas de pedra: a graça do Espírito, na fé em cristo.” (CHENU, 2006, p. 50). Para desenvolver essa ideia, Abelardo se apoiou em Santo Agostinho ( $A$ doutrina cristã) e nos preceitos de São Paulo (5-67). Segundo Abelardo (1971, p. 26),

porque também o bem-aventurado Agostinho, ao considerar todo preceito ou proibição que reconduz para a caridade, ou antes para o desejo que para as obras, diz: a lei a nada prescreve que náo seja a caridade e a nada proíbe que não seja o desejo. Donde também o apóstolo [São Paulo]: Toda lei, diz ele, se completa numa só frase "amarás a teu próximo como a ti mesmo". E novamente: "o amor é a plenitude da lei". 
Diante de todos os caminhos que o indivíduo poderia seguir para preferir a vontade de Deus à sua, caso ainda viesse a pecar, existiria, para Abelardo, outro caminho a ser seguido, o do arrependimento e a busca de reparaçáo. O livre-arbítrio poderia levar o homem a pecar, contudo, o mesmo livre-arbítrio poderia levá-lo a querer buscar a reparação dos seus erros, como também poderia levá-lo a preferir a vontade de Deus à sua própria. Para Abelardo, seria necessário seguir três passos: o remorso (penitência), a confissão e a reparaçáo (penitentia, confessio, satisfactio) (ABELARDO, 1971, p. 76). No que concerne ao remorso, Abelardo o definiu como um sentimento de dor, de culpa, que o indivíduo experimenta em relação às suas decisōes: "Penitência [remorso], porém, se diz propriamente uma dor da alma a respeito do que se errou, quando alguém evidentemente está pesaroso por ter [se] excedido em alguma coisa." (ABELARDO, 1971, p. 76).

Essa dor sentida pelo indivíduo pode ser revertida pela penitência e pela disposição em reverter a situação pecaminosa, podendo reparar o seu erro junto a Deus. Diante disso, Abelardo propôs, então, uma reconciliação com Deus pela penitência. Em qualquer momento o indivíduo poderia se arrepender e buscaria, assim, a reconciliação. Conforme Abelardo (1971, p. 88):

Nesse gemido, imediatamente nós somos reconciliados com Deus, e obtemos a graça precedente, tanto como aquele [dizer] do profeta: "Em qualquer hora que o pecador se tenha lamentado será salvo", isto é, pela salvação de sua alma ele se fará digno. Não diz qual ano, ou qual mês, ou mesmo qual semana, ou qual dia, mas "qualquer hora", de modo que ele anuncia sem demora a graça merecida, nem deve ser eterna a pena, a qual consiste na condenação do pecado. Ainda que efetivamente precedido pelo momento preciso da necessidade, ele náo tenha de chegar a um lugar para a confissão, ou de realizar a reparação, de modo nenhum nesse gemido acerca dessa vida incorreria afastar-se do inferno, porque é pecado abandonar a Deus, isto é, ele [pecador] tornar-se tal que já não seja digno de, do mesmo modo que antes por causa daquele pecado que precedeu, eternamente ser punido por Deus.

Em se tratando de confissão, Abelardo questionou sua serventia, já que Deus, como criador, saberia de todas as coisas: "Mas não vejo que é que valha a confissão junto a Deus que examinou tudo [em nós] ou qual indulgência ele obtém de nós pela língua.” (ABELARDO, 1971, p. 98). Como resposta, Abelardo afirmou que confiar o pecado a Deus seria um ato de humilhação que, por si só, já representaria uma parte da penitência. Confia-se a Deus a 
própria liberdade e o orgulho; para tanto, deveria procurar fazer a confissão a um sacerdote que ocupava, a seu ver, o lugar do "médico". Conforme Abelardo (1971, p. 98, 100),

entấo também porquanto na humildade da confissão se faz grande parte da reparaçáo [...]. Enfim, os sacerdotes aos quais são confiadas as almas que confessam, a elas têm juntado as reparaçóes da penitência, a fim de que os que mal e soberbamente usaram seu arbítrio sejam corrigidos pelo arbítrio de poder alheio, e que tanto mais seguramente o façam quanto obedecendo a seus prelados sigam a vontade não tão a sua quanto a de outros [...]. O sacerdote ocupa verdadeiramente o lugar do médico, de quem, como dissemos, a reparação deve ser estabelecida.

Abelardo chegou a questionar o caso de não haver um sacerdote presente, a quem se deveria confessar os pecados. Ele afirmou que se não houvesse um superior a quem se confessar, o melhor seria obedecer somente a Deus, sem confiar seu pecado a nenhum outro homem leigo, já que provavelmente este não poderia ser digno de impor uma penitência segundo os desígnios de Deus ${ }^{9}$. Abelardo exemplificou o caso do apóstolo Pedro:

Existem aqueles aos quais pareça Pedro - que estava à frente dos demais todos e não tinha um superior a quem tivesse confiado a alma - de modo algum ter como necessário ao homem confessar o pecado, tal como se a reparação por aquele lhe tivesse devido ser instituída, e como se ao preceito dele quase como ao de um superior obedecesse. (ABELARDO, 1971, p. 102).

Nesse caso, Abelardo assegurou a autonomia de Pedro, que estava livre para julgar a si mesmo. E essa mesma ação poderia ser estendida aos demais. O perdão poderia ser obtido de forma direta quando o indivíduo reconhecesse sua culpa e pudesse se confessar diretamente com Deus. O sacerdote seria apenas um intermediário. Para a conclusão dessa análise, Abelardo se apoiou na passagem de 1 Coríntios 11,31: "Se nós examinássemos a nós mesmos, não seríamos julgados." Ele explicou a passagem da seguinte forma:

\footnotetext{
9 Segundo Gandillac (1945): "Parece que Abelardo desvaloriza a absolvição propriamente dita como realidade sacramental. Para ele, o papel do sacerdote é antes de tudo determinar a pena. É nessa perspectiva que é necessário considerar a heresia concernente ao poder das chaves." (ABELARDO, 1945 , p. 200, nota 1, grifo nosso).

Tese condenada no Concílio de Sens: "Que o poder de ligar e desligar teria sido dado apenas aos apóstolos, não também aos sucessores destes.” (MEWS, 2001, p. 109).
} 
Se nós mesmos puníssemos ou corrigíssemos nossos pecados, de modo algum por nós mesmos deveríamos mais gravemente ser punidos. Seguramente, quando a grande misericórdia de Deus nos abandona a nosso julgamento, é para que Ele próprio não [nos] puna mais pesadamente. (ABELARDO, 1971, p. 108).

Contudo, Abelardo advertiu que existia ainda um tipo de pecado que não teria perdão. Mesmo que o indivíduo pudesse encontrar um sacerdote ou se confessasse a si mesmo, não conseguiria absolvição. Esse é o pecado irremediável (peccatum irremisibilis) que está entre os pecados considerados mais graves (peccatum grauis), que resultam em crimes e prejudicam a honra de quem os comete (ABELARDO, 1971, pp. 68 e 70). Segundo Abelardo, o pecado irremediável seria aquele que faz o indivíduo duvidar da bondade de Deus (bonitate Dei) ou Espírito Santo (Spiritum Sanctum) (ABELARDO, 1971, p. 94). Isso significa que o pecado irremediável seria aquele em que se atribuiu o feito do bem ao diabo e não a Deus. Nas palavras de Marcos 3,28-30:

$\mathrm{Na}$ verdade, eu vos digo: tudo será perdoado aos filhos dos homens, os pecados e todas as blasfêmias que tiverem proferido. Aquele, porém, que blasfemar contra o Espírito Santo [bondade de Deus], jamais será perdoado: é culpado de pecado eterno. Isto porque eles diziam: "Ele está possuído por um espírito impuro [diabo].”

Rémusat (1855) esclareceu a análise de Abelardo. Seria "de qualquer modo, atribuir ao diabo o que é feito pela bondade em sua misericórdia; é dizer, o espírito ruim, ou que Deus é o diabo" (RÉMUSAT, 1855, p. 472).

O caminho para o pecado irremediável seria a excomunhão, tema analisado por Abelardo nos Commentaria super sancti Pauli epistolam ad Romanos.

\section{Crença, graça divina e livre-Arbítrio}

Como Abelardo compreendeu o pecado em relação à crença do indivíduo? O que Abelardo analisou na Ethica foi que a ideia de crença se relacionava diretamente com a vontade do indivíduo e com a vontade de Deus. Ambas deveriam estar em conformidade e se o indivíduo pudesse crer nessa relação, a intenção consequentemente seria com certeza boa. A vontade de Deus estaria sempre acima da do indivíduo, contudo, para Abelardo, 
a crença não era suficiente para que se alcançasse algum bem. Ela deveria necessariamente estar atrelada à vontade de Deus.

Vimos que Abelardo afirmou a existência do pecado por ignorância, ou seja, pela ausência da fé, ou mesmo pelo pecado original, contudo, esses tipos de pecados não eram tão firmes como o pecado em que a intençáo se colocaria como consciente, em que o indivíduo consentiria no mal, e, portanto, desprezaria a Deus.

Para Abelardo, não existe a obediência cega. Seguimos regras dos nossos pais, por exemplo, porque acreditamos que deveriam ser honradas. Com esse mesmo espírito de compreensão o indivíduo deveria seguir as leis de Deus. O livre-arbítrio ou vontade poderia aparecer em um momento de discórdia ou de arrependimento. Abelardo chamou a esse ato voluntário de "contrição interior" ou "contrição do coração" (ABELARDO, 1971, p. 88). Por ele, o pedido de reconciliação, por exemplo, seria imediato. Amar a Deus e seguir sua vontade deveria vir do coração, deveria ser um ato livre.

Em relação à graça divina, Abelardo foi acusado de excluí-la no processo de salvação do indivíduo. Tanto Guilherme de Saint-Thierry quanto Sáo Bernardo afirmaram que, para Abelardo, o livre-arbítrio por si só seria suficiente para a salvação, excluindo, assim, a necessidade da graça ${ }^{10}$. Contudo, para Abelardo, a graça divina era de fundamental importância para a salvação do indivíduo. Pela graça, os homens poderiam se redimir de seus pecados e também amenizar o peso do pecado original.

Para Agostinho, por exemplo, a graça divina era essencial para que os homens fossem salvos (AGOSTINHO, 1996, p. 70). Questionou na Cidade de Deus quem em sã consciência se sujeitaria a "maus demônios" e não a Deus (AGOSTINHO, 1996, p. 436). Para Abelardo, o livre-arbítrio era dado por Deus, contudo, era governado pela natureza humana, cheia de vícios. Enquanto fosse seguida a vontade de Deus, o indivíduo estaria realmente livre, sem a sujeição a nenhum tipo de vícios.

Segundo Rémusat (1855), o termo "graça" não apontou para algo específico na filosofia e na teologia do palatino e, muitas vezes, até se apresentou com um sentido incerto. Contudo, a graça parece importante

\footnotetext{
${ }^{10}$ Carta 326: "Porque pelo livre-arbítrio, sem a graça como ajudante, bem podemos tanto desejar como agir." (BERNARDO, 1859, p. 532).

Tese condenada no Concílio de Sens: "Que o livre-arbítrio por si seria suficiente para algum bem." (MEWS, 2001, p. 108).
} 
quando estabelece com Deus uma relação de bondade. Conforme Rémusat (1855, p. 509):

$\mathrm{Na}$ linguagem e na doutrina de Abelardo, a graça é provável de ser alguma coisa mais geral e mais abstrata. [...] Parece armazenar todas as disposiçóes de sabedoria eterna, que se pode chamar justamente de graças de Deus, no sentido de bem-feitos, todas essas harmonias da ordem universal, todas essas revelaçóes que se destacam da constituição do mundo e daquela da razão, em uma palavra, tudo o que testemunha ao filósofo como ao cristáo a bondade infinita.

Observamos na ética abelardiana que tanto a moral filosófica quanto a moral teológica pressupóem o livre-arbítrio. Os cristãos mais tradicionais acreditavam que o livre-arbítrio foi perdido depois do pecado original, mas, para Abelardo, ele estava vivo e a salvação era algo possível. Vimos em Abelardo que a maioria das formas de pecados eram dignas de perdão, bastando clamar a Deus, salvo o pecado irremediável.

Assim, entendemos que para Abelardo a graça divina era importante, mas não decisiva na hora da salvação. A graça seria a bondade de Deus que se manifestava no indivíduo no intuito de ajudá-lo a intencionar e a consentir melhor, a se aproximar da natureza divina. Contudo, o indivíduo poderia se aproximar, clamar a Deus se assim desejasse a graça, caso contrário continuaria como pecador. Pecar, dessa forma, era para Abelardo uma decisão interna, fruto da vontade e do livre-arbítrio.

\section{Conclusão}

Cano-Alarcón (1994) se propôs a analisar a moral desenvolvida por Abelardo na Ethica no artigo "Las fuentes de la moralidad según Pedro Abelardo" a partir de algumas fontes historiográficas dos principais comentadores de Abelardo. Apontou como muitos autores desenvolveram a ideia de que a "moral da intenção" proposta por Abelardo, na verdade, seria uma "moral subjetivista", pois viam Abelardo como "um precursor da atual moral subjetivista” (CANO-ALARCÓN, 1994, p. 303).

Contudo, o fato de Abelardo ter analisado o pecado a partir da própria consciência do indivíduo fez dele um "subjetivista", ou seja, um autor que 
desconsiderou os preceitos cristãos para favorecer o que o indivíduo pensava ou acreditava ser verdade?

O rótulo de "subjetivista" proposto por alguns autores sustentam as acusações que Abelardo recebeu no Concílio de Sens em relação à imagem de um indivíduo que não precisaria de Deus como guia, bastando somente sua vontade e livre-arbítrio. Assim, se reconhece apenas Abelardo como filósofo, como se ele tivesse pregado algum tipo de desprezo à religiosidade. Se pensarmos a moral desenvolvida por Abelardo somente em termos filosóficos, o indivíduo é um ser consciente, que sabe se agiu de forma correta ou não, sabe se pecou ou não, salvo os pecados cometidos por ignorância. Esse "saber" traz o indivíduo para o mundo subjetivo, consciente de si mesmo ("conhece-te a ti mesmo"), contudo, os parâmetros morais que o indivíduo carrega, o que o faz discernir o que é correto ou não em sua cultura deveria, para Abelardo, estar atrelado aos preceitos de Deus. No século XII, o cristão não tinha como fugir dessa regra.

Não devemos nos esquecer que Abelardo também desenvolveu um trabalho no campo da teologia, apesar de ter se utilizado da filosofia como suporte à primeira. Ressaltou Cano-Alarcón (1994, p. 329-330): “É um engano julgar Scito te ipsum [a Ethica] como uma construção puramente subjetiva já que a subjetividade do consentimento e da intenção é colocada por Abelardo em confronto com um valor teológico, a lei divina, uma norma exterior com a que a subjetividade deve coincidir." Logo, as ideias difundidas por Abelardo na Ethica estavam atreladas aos preceitos cristãos. O fato de Abelardo ter construído a ideia de um indivíduo dotado de consciência não o redimiria de suas responsabilidades. Ser responsável é ser livre e essa liberdade deveria conduzi-lo aos desígnios de Deus, à sua obediência, a querer o que Ele quisesse. Dessa forma, a intenção do indivíduo deveria voltar-se a seu favor.

$\mathrm{O}$ que pareceu motivar Abelardo em pensar dessa forma não foi propriamente a filosofia, mas a fé religiosa. Entretanto, a fé se liga diretamente com o amor (caridade). Ela também se torna filosófica quando analisamos o indivíduo no âmbito moral, na sua capacidade de crer e, consequentemente, de poder intencionar e consentir o que crê, responsabilizando-se por suas falhas. Para tanto, em Abelardo, a necessidade de o indivíduo se ligar à vontade de Deus se torna necessária para uma vida moral digna. 
DIEBE, E. P. Free will in the ethical writings of Abelard. Trans/Form/Ação, Marília, v. 42, p. 231-248, 2019. Edição Especial.

ABSTRACT: Abelard's conception of free will was defined in the work Theologia scholarium as the deliberation of the individual to do or renounce something. In Abelard's ethical writings, this idea was developed on the basis of the notion of the voluntary. In his treatment of sin, the basis of Abelard's discussions, Abelard developed the concept currently known as "intentionalist morals". In this moral perspective, sin would only result from the intention of the individual, as the result of his or her consent and of free and voluntary action. The purpose of this article is to introduce Abelard's idea of free will in relation to sin and God's will, a position that contributed to his condemnation at the Council of Sens in 1140.

Keywords: Peter Abelard (1079-1142). Ethics. Free will. Voluntary. Consent.

\section{REFERÊNCIAS}

ABELARDO, P. Confessio fidei universis. Edição Victor Cousin, 1849. Tradução: Cléber Eduardo dos Santos Dias. Veritas, Porto Alegre, v. 51, n. 3, p. 169-181, 2006.

ABELARDO, P. Ethics (Ethica). An edition with introduction english translatio and notes by D. E. Luscombe. Oxford: At the Clarendon Press, 1971. (Edição Bilíngue).

ABELARDO, P. Euvres choisies d'Abélard. Texte présentés et traduits par Maurice de Gandillac. Paris: Éditions Montaigne, 1945.

ABELARDO, P. Theologia Scholarium. In: Opera omnia. Accedunt Hilarii et Berengarii (Abaelardi discipulorum), Parisiis: J. -P. Migne, 1855. p. 979-1114. Tomus Unicus (Patrologiae Latinae n. 178).

AGOSTINHO, S. Bispo de Hipona. Opera omnia. Paris: J.-P. Migne, 1865. V.10 (Patrologiae Latinae n. 44).

AGOSTINHO, S. Cidade de Deus. 2. ed. Tradução: J. Dias Pereira. Lisboa: Fundação Calouste Gulbekian, 1996. V. 1.

BERNARDO, S. Opera omnia. Paris: J.-P. Migne, 1859. V. 1 (Patrologiae Latinae n. 182).

BÍBLIA de Jerusalém. São Paulo: Editora Paulus, 2002.

CANO ALARCÓN, M. J. Las fuentes de la moralidad según Pedro Abelardo. Anuário de Historia de la Iglesia, Espaná: Universidad de Navarra, n. 3, p. 301-330, 1994. 
CHAVES-TANNÚS, M. A “Ética" de Pedro Abelardo: um modelo medieval de aplicação da lógica à moral. Uberlândia: EDUFU, 1996.

CHENU, M.-D. O despertar da consciência na civilização Medieval. Tradução: Juvenal Savian Filho. São Paulo: Loyola, 2006.

DE LIBERA, A. La querelle des universaux: de Platon à la fin du Moyen Age. Paris: Éditions du Seul, 1996.

ESTÊVĀO, J. C. Sobre a consciência e teologia em Abelardo. Cadernos de Trabalho CEPAME, São Paulo: USP, v. 1, n. 3 p. 49-58, 1992.

KING, P. Abelard's intentionalist ethics. The Modern Schoolman, USA: Philosophy Documentation Center, n. 72, p. 213-231, 1995.

MEWS, C. J. The list of heresies imputed to Peter Abelard. In: Abelard and his legacy London: Ashgate, 2001. p. 73-110. (Variorum Collected Studies Series).

RÉMUSAT, M. C. Abélard: sa vie, sa philosophie \& sa théologie. Paris: Didier, 1855. Tome I.

VERBEKE, G. Éthique et connaissance de soi chez Abélard. In: BECKMANN, J. P.; HONNEFELDER, L.; SCHIRIMPF, G.; WIELAND, G (org.). Philosophie im Mittelalter. Entwicklungslinien und Paradigmen. Hamburg: Felix Meiner, 1987. p. 81101.

ZERBI, P. Philosophi e logici: un vetennio di incontri e scontri: Soisson, Sens, Cluny (1121-1141). Roma: Palazzo Borromini, 2002.

Recebido: 30/12/2019

Aceito: 30/12/2019 
DIEBE, E. P. 